\title{
Spatio-temporal characteristics of meteorological drought under changing climate in semi-arid region of northern Ethiopia
}

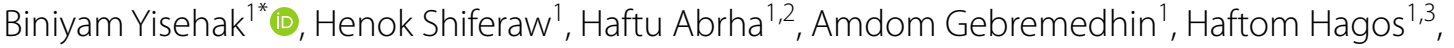 \\ Kelali Adhana ${ }^{1}$ and Temesgen Bezabh ${ }^{1}$
}

\begin{abstract}
Background: Below-normal availability of water for a considerable period of time induces occurrence of drought. This paper investigates the Spatio-temporal characteristics of meteorological drought under changing climate. The climate change was analyzed using delta based statistical downscaling approach of RCP 4.5 and RCP 8.5 in R software packages. The meteorological drought was assessed using the Reconnaissance Drought Index (RDI).

Results: The result of climate change projections showed that the average annual minimum temperature will be increased by about $0.8-2.9^{\circ} \mathrm{C}$. The mean annual maximum temperature will be also increased by $0.9-3.75^{\circ} \mathrm{C}$. The rainfall projection generally showed an increasing trend, it exhibited an average annual increase of $3.5-13.4 \%$ over the study area. The projected drought events reached its maximum severity indicated extreme drought in the years 2043, 2044, 2073, and 2074. The RDI value shows drought will occurred after 1-6 and 2-7 years under RCP 4.5 and RCP 8.5 emission scenarios respectively over the study area. Almost more than $72 \%$ of the current and future spatial coverage of drought in the study area will be affected by extreme drought, $22.3 \%$ severely and $5.57 \%$ also moderate drought.
\end{abstract}

Conclusions: Therefore, the study helps to provide useful information for policy decision makers to implement different adaptation and mitigation measures of drought in the region.

Keywords: Climate change, Projection, Meteorological drought, RDI, Drought characteristics

\section{Background}

Droughts is regularly happened during the past century across the globe (Rivas-Martínez et al. 1999), these droughts produced huge socio-economic and environmental influences in this semi-arid region resulting in massive-scale migration, famine and desertification, particularly during the last two drought events (Masih et al. 2014). Climate change related meteorological droughts historically have been major causes for loses lives, environmental loses, and forced millions of people to displace and live in poverty (Gebrehiwot et al. 2011). More

\footnotetext{
*Correspondence: b1n1y21@gmail.com

${ }^{1}$ Institute of Climate and Society, Mekelle University, Mekelle, Ethiopia Full list of author information is available at the end of the article
}

specific figures from recent drought events in Tigray region exemplify the magnitude of drought-associated impacts. For example, the meteorological drought of 2003 happened in northern highlands of Ethiopia led to the worst famine since the mid-1980 s that affected 13.5 million people (Wagaw et al. 2005). In spite of the recurrent and devastating nature of drought in different areas of Tigray, it has received far less attention. Therefore, this study is interested to explore drought event to understand its severity, intensity, frequency, duration, and its spatial extent in different areas using data generated over the specified period.

It is also one of natural hazard explained by a substantial reduction in water availability throughout a prolonged period of time over a given area (Sousa et al. 
2011). For instance, drought in Ethiopia is one of the main natural disasters throughout the human history (Gebrehiwot et al. 2011). It has become a main concern in the northern highlands of the country particularly in Tigray region where food security and environmental damages were commonly observed (Nicholson 2000). Kanellou et al. (2008) and Loukas and Vasiliades (2004) argue that Spatio-temporal characteristics of meteorological drought study are important to understand the regional severity of drought to manage it effectively and to reduce the agricultural production losses and to protect the environment.

Drought has increased in most places of Ethiopia, which consistent with expectations for a warming climate. The changing earth temperature could increase evaporation demand and increased spatio-temporal variability of droughts in the coming period (Ault et al. 2016). Long dry spells are often caused by climate change: duration, intensity and frequency have increased in the past drought events (Stocker 2014). Such incremental trend is projected to continue during the 21st century as a consequence of climate change (Stocker 2014).

Numerous standardized drought indices are developed by researchers for drought assessment based on different hydro-climatic variables, such as precipitation, streamflow, soil moisture, temperature, and runoff, each drought index has their own limitation (Yisehak and Zenebe 2020). For instant in arid and semi-arid regions, drought events computed by over a long time period can occur with the same frequency at all locations because of the standardization of the index. Moreover, SPI value computed at short time steps for the regions of high precipitation may result in misleadingly large negative or positive SPI. However, in arid and semi-arid regions, high temperature along with shortage in precipitation is an important factor responsible for the development and progression of droughts (Thomas et al. 2016). In this regard, Reconnaissance Drought Index (RDI) has been used by many researchers for identifying the meteorological drought characteristics as it is more suited to arid and semi-arid areas (Thomas et al. 2016).

Several researches have been carried out on droughts and related issues in semi-arid highlands of northern Ethiopia. Most of those researches used Standardized Precipitation Index (SPI). For instance, Gidey et al. (2018) Standardized Precipitation Index (SPI) was used to predict meteorological drought hazard under medium emission scenarios in Northern Raya Valley. Bayissa et al. (2015) also used SPI to study the effect of the length of records and to characterize drought in the Upper Blue Nile Basin. However, to overcome the adverse limitation of SPI, it's essential assess meteorological drought based on RDI under both high and medium emission scenarios in semi-arid highlands of northern Ethiopia.

Thus, the overall objectives of this study are to analyze and assess the spatial-temporal variation of meteorological drought in semi-arid highlands of northern Ethiopia, using the RDI under both high and medium climate change emission scenarios. Moreover, we tried to characterize the meteorological droughts, duration, severity, intensity, relative frequency and to map out the spatial extent of drought using GIS applications for better understanding drought severity in the near-term, midterm, and end-term. The results can provide support policy decision-making, effective drought monitoring, and early warning system in the region.

\section{Materials and methods \\ The study area}

The study was conducted in four districts (Raya Azebo, Enda-Mekoni, Ofla, and Raya Alamata) of Southern zone of Tigray regional state. Geographically, they are located between $12^{\circ} 15^{\prime} 27^{\prime \prime}$ up to $12^{\circ} 56^{\prime} 38^{\prime \prime} \mathrm{N}$ latitude and $39^{\circ} 10^{\prime} 34^{\prime \prime}$ up to $39^{\circ} 58^{\prime} 56^{\prime \prime} \mathrm{E}$ longitude and have a total land area of $6651 \mathrm{~km}^{2}$. The districts receive up to an average of $766 \mathrm{~mm}$ of rainfall annually for the period of (1980-2009). Rainfall is erratic and bimodal in this area (Ayenew et al. 2013). During the last 30 years, the maximum $\left(\mathrm{T}_{\max }\right)$ and minimum temperature $\left(\mathrm{T}_{\min }\right)$ were 28 up to 33 and 14 up to $16^{\circ} \mathrm{C}$ respectively (Gidey et al. 2018) (Fig. 1).

\section{Data and data sources}

Thirty years daily meteorological data such as rainfall, maximum temperature, and minimum temperature for the period 1980-2009 obtained from the National Meteorological Agency (NMA) were collected from four meteorological stations. Fortunately, all districts have meteorological stations and located in Mekoni, Maichew, Korem and Alamata respectively (Table 1). Some data were missed and inconsistency was also observed. To fill out the missing meteorological data AgMIP data were used.

\section{Climate modelling}

The future climate for all districts were projected for near-term (2010-2039), mid-term (2040-2069), and endterm (2070-2099), climate scenarios generated based on Agricultural Model Inter-comparison and Improvement Project (AgMIP) climate team methodology presented in Rosenzweig et al. (2013) under two Representative Concentration Pathways (RCPs), RCP 4.5 (with radiative forcing expected to stabilize at $4.5 \mathrm{~W} / \mathrm{m}^{2}$ by 2100 ) and RCP 8.5 (with radiative forcing which is expected $8.5 \mathrm{~W} / \mathrm{m}^{2}$ by 2100 ) were generated for better understanding of the 


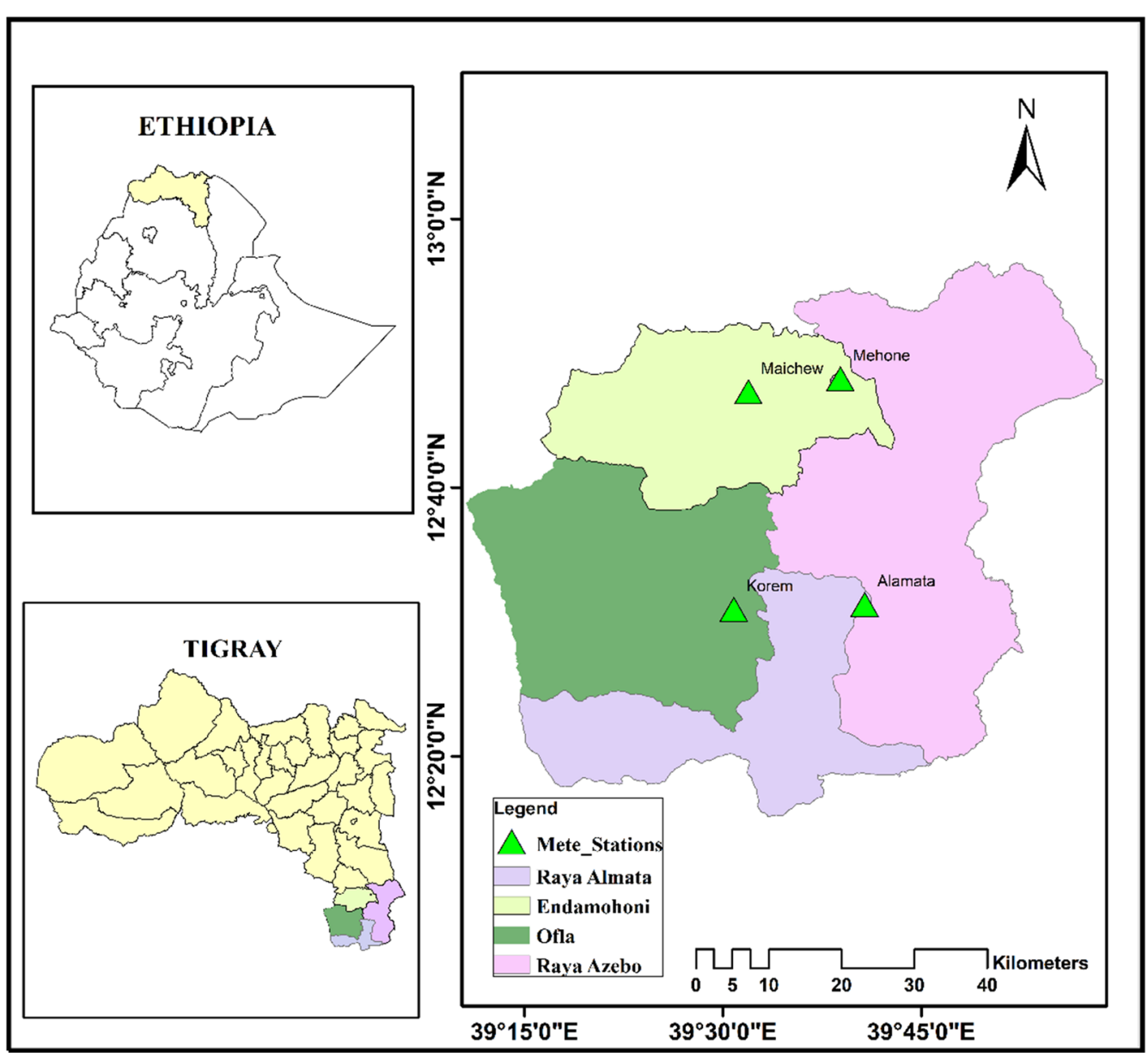

Fig. 1 Location of study area

Table 1 Location of meteorological stations in the study area

\begin{tabular}{llllll}
\hline SN & Stations & Longitude $(\mathrm{E})$ & Latitude $(\mathrm{N})$ & $\mathrm{Z}(\mathrm{m})$ & Period \\
\hline 1 & Alamata & 39.71 & 12.42 & 1589 & $1980-2009$ \\
2 & Korem & 39.50 & 12.51 & 2450 & $1980-2009$ \\
3 & Maichew & 39.53 & 12.78 & 2432 & $1980-2009$ \\
4 & Mekoni & 39.65 & 12.80 & 1590 & $1980-2009$ \\
\hline
\end{tabular}

adverse impacts of climate change in the region under high and medium scenarios. The climate scenarios were created from the Couple Model Intercomparison Project Phase 5 (CMIP5) of an ensemble of 5 General Circulation Models (GCMs) based on the series baseline (19802009) daily climate data by applying the delta change method computed in R-programming.

Numerous climate modeling approaches have been tested in the past decades (Giorgi et al. 1992; Kim et al. 2014; Pal et al. 2000), such as the delta change approach
(Hay et al. 2000), the multiplicative correction (Graham et al. 2007), the monthly non-linear correction (Bordoy and Burlando 2013) and power transformation (Leander and Buishand 2007). Some of the approach consist of correcting the mean error, while others focus on both average and variance or on the correction of mean and standard deviation (Teutschbein and Seibert 2013). While, delta change approach focus on extremes is needed for extreme event analysis such as flood and drought. Therefore, in this study the delta change approach has been applied. This approach has the advantage of taking into account both change mean and in the extremes (Ouédraogo et al. 2019; Sarr et al. 2015).

In this study, for the period of 2010-2018 was considered as model validation by comparing observed and projected climate model. The performance of climate model evaluated using the root mean square error (RMSE), the mean absolute error (MAE), the relative error (RE), and coefficient of determination $\left(\mathrm{R}^{2}\right)$. Form the total 26 General Circulation Models (GCMs) five GCMs were 
selected such as Community Climate System Model (CCSM4), GGFDL-ESM2M, HadGEM2-ES (Met Office Hadley Centre) of UK, MIROC5 (Model for Interdisciplinary Research on Climate) and MPI-ESM-MR. Those were selected based on their consistency, and resolution performance for East and sub-Saharan Africa (Rosenzweig et al. 2013; Sillmann and Roeckner 2008).

\section{Drought indices analysis}

\section{Estimation of evapotranspiration (ETo)}

Drought index calculator (DrinC) provides a module for the calculation of PET with the following temperature based methods: Hargreaves and Samani 1982, 1985; Rivas-Martínez et al. 1999 and Blaney-Criddle Doorenbos 1975). In this study the Hargreaves and Samani method has been used to estimate reference evapotranspiration (ETo) as described as following below:

$$
E T o_{H a r}=0.0023 R a\left(T_{\max }-T_{\min }\right)^{0.5}\left(\frac{T_{\max }-T_{\min }}{2}+17.8\right)
$$

where, $E T o_{H a r}=E T o$ estimated by the Hargreaves equation ( $\mathrm{mm}$ day-1); $\mathrm{Ra}=$ extraterrestrial radiation (MJ $\mathrm{m}-2$ day-1); $\mathrm{T}_{\max }=$ maximum air temperature $\left({ }^{\circ} \mathrm{C}\right)$; $\mathrm{T}_{\min }=$ minimum air temperature $\left({ }^{\circ} \mathrm{C}\right)$.

\section{Reconnaissance Drought Index (RDI)}

Drought severity was assessed through the computation of RDI. The RDI was developed to approach the water deficit in a more accurate way, as a sort of balance between input and output in a water system (Tsakiris and Vangelis 2005; Tsakiris et al. 2007). The RDI calculated based both on cumulative Precipitation (P) and Potential Evapotranspiration (PET), which are measured (P) and calculated (PET). The calculation method of PET, however, does not seem to affect the results of RDI in any way (Vangelis et al. 2013).The initial value $\left(\alpha_{\mathrm{k}}\right)$ of RDI calculated for the $\mathrm{i}^{\text {th }}$ year in a time basis of $\mathrm{k}$ (months) as describe as following below:

$$
\alpha_{k}^{i}=\frac{\sum_{j=1}^{k} P i j}{\sum_{j=1}^{k} P E T i j}, i=1(1) N a n d j=1(1) K
$$

where, $\mathrm{P}_{\mathrm{ij}}$ and $\mathrm{PET}_{\mathrm{ij}}$ are the cumulative precipitation and potential evapotranspiration of the $j^{\text {th }}$ month of the ith year respectively and $\mathrm{N}$ is the total number of years of the available data.

$$
R D I^{i}=\frac{Y^{i}-\bar{Y}}{\hat{\delta}_{y}}
$$

where, $\mathrm{Y}_{\mathrm{i}}$ is the $\ln \left(\alpha_{k}^{i}\right), \bar{Y}$ is its arithmetic mean and $\hat{\delta}_{\mathrm{y}}$ is its standard deviation.
In case the gamma distribution is applied, the RDI can be calculated by fitting the gamma probability density function (pdf) to the given frequency distribution of $\alpha \mathrm{k}$ (Tigkas 2008; Tsakiris et al. 2008). For short reference periods (e.g. monthly or 3-months) which may include zero values for the cumulative precipitation of the period, the RDI can be calculated based on a composite cumulative distribution function including: the probability of zero precipitation, and the gamma cumulative probability.

Positive values of RDI indicate wet periods, while negative values indicate dry periods compared with the normal conditions of the area. The severity of drought events increases when RDI values are getting highly negative. According to Tigkas et al. 2013 RDI drought severity can be categorized in mild, moderate, severe and extreme classes, with corresponding boundary values of RDIst ( -0.5 to -1.0$),(-1.0$ to -1.5$),(-1.5$ to -2.0$)$, and (< $-2.0)$, respectively.

The gamma distribution was applied; the RDI calculated by fitting the pdf to the given frequency distribution of $\alpha_{\mathrm{k}}$. RDI has been determined for the current and future periods for a hydrological year in 12-month time scale.

\section{Drought characteristics}

In this study, RDI meteorological drought indicators were used and calculated for 12 months. The negative and positive values of RDI are considered as the drought and non-drought events, respectively. As drought is defined when the values of RDI fall below zero, a drought event is considered a period with negative RDI values. In order to measure length of drought duration and magnitude of drought severity, a threshold value must be defined.

Drought duration (D): the period length in which the RDI is continuous negative, started from the SPI values is equal to minus one and ends when the RDI values turn out to be positive.

Drought severity (S): the cumulated SPI values within the drought duration, which is defined by Eq. 3 and intensity of drought is the ratio of severity of drought to its duration.

$$
S=-\sum_{i=1}^{D} R D I_{i} 3
$$

The relative frequency (RF): the ratio of number of years with drought events (n) (Negative RDI) to number of total years $(\mathrm{N})$, as defined by Saravi et al. (2009). 


$$
R F=\frac{n}{N} \times 1004
$$

\section{Spatial variation maps of drought severity}

The inverse distance weighted (IDW) method was used to map the spatial extent of drought from point data. It is intuitive and efficient for spatial analysis (Shepard 1968). The analysis was done using Geostatistical analysis tool of ArcMap 10.2.

\section{Results and discussion}

\section{Climate change modelling}

The temperatures were increased with the time period in both RCP's overall districts. The highest minimum and maximum temperature were simulated during the end term period under RCP 8.5 (Tables 2 and 3). The highest temperature was recorded in Raya Azebo and EndaMekoni district $\left(4.2^{\circ} \mathrm{C}\right.$ and $\left.3.4{ }^{\circ} \mathrm{C}\right)$ in RCP 8.5 for both minimum and maximum temperatures respectively. The lowest temperatures recorded were $0.6{ }^{\circ} \mathrm{C}, 1.0^{\circ} \mathrm{C}$, $0.9^{\circ} \mathrm{C}$, and $1.0^{\circ} \mathrm{C}$ for Raya Alamata, Ofla, Enda Mekoni and Raya Azebo districts in RCP 4.5 near-term periods respectively. Numerous investigation also clearly shown that average annual minimum and maximum temperature are predictable to increase in the future (Araya et al. 2015; Ashenafi 2014). For instant, Elshamy et al. (2009) shows average annual temperature increase over the northern Ethiopia between $2{ }^{\circ} \mathrm{C}$ and $5{ }^{\circ} \mathrm{C}$ at the end of the 21st Century compared to the baseline period. In the Raya Azebo, mean annual rainfall was increased by $28.7 \%$ during the end term period under RCP 8.5 , while in Ofla increased by $1.6 \%$ (Table 4 ). The climate projection result shows the precipitation projection exhibited an increase in annual mean rainfall. Future projections of rainfall are more complex to disentangle unlike temperature. Elshamy et al. (2009) indicate a future projection positive shift of change in rainfall magnitude for most of east Africa, including Ethiopia. The model validation was evaluated on a monthly basis to test performance of the climate model. The model performance statistics (RMSE, MAE, RE, and $\mathrm{R}^{2}$ ) are summarized in Table 5.

Table 2 Changes in Temperature minimum $\left({ }^{\circ} \mathrm{C}\right)$ compared to the baseline over the four districts in RCP 4.5 and RCP 8.5

\begin{tabular}{|c|c|c|c|c|c|c|}
\hline \multirow[t]{2}{*}{ Districts } & \multicolumn{3}{|l|}{ RCP 4.5} & \multicolumn{3}{|l|}{ RCP 8.5} \\
\hline & Near term & Mid term & End term & Near term & Mid term & End term \\
\hline Raya Alamata & 0.9 & 1.5 & 1.7 & 1.0 & 2.1 & 3.7 \\
\hline Ofla & 1.0 & 1.8 & 2.3 & 1.0 & 2.5 & 4.1 \\
\hline Enda-Mekoni & 1.0 & 1.7 & 2.2 & 1.0 & 2.3 & 3.0 \\
\hline Raya Azebo & 1.0 & 2.0 & 2.3 & 1.0 & 2.5 & 4.2 \\
\hline
\end{tabular}

Table 3 Changes in Temperature maximum $\left({ }^{\circ} \mathrm{C}\right)$ compared to the baseline over the four districts in $\mathrm{RCP} 4.5$ \& RCP 8.5

\begin{tabular}{|c|c|c|c|c|c|c|}
\hline \multirow[t]{2}{*}{ Districts } & \multicolumn{3}{|l|}{ RCP 4.5} & \multicolumn{3}{|l|}{ RCP 8.5} \\
\hline & Near term & Mid term & End term & Near term & Mid term & End term \\
\hline Raya Alamata & 0.6 & 1.4 & 1.6 & 1.0 & 1.7 & 1.9 \\
\hline Ofla & 1.0 & 1.8 & 2.3 & 1.2 & 2.6 & 3.3 \\
\hline Enda-Mekoni & 0.9 & 1.6 & 2.1 & 1.2 & 2.4 & 3.4 \\
\hline Raya Azebo & 1.0 & 1.6 & 2.1 & 1.2 & 2.6 & 3.0 \\
\hline
\end{tabular}

Table 4 Changes in annual rainfall (\%) compared to the baseline over four districts in RCP 4.5 \& RCP 8.5

\begin{tabular}{|c|c|c|c|c|c|c|}
\hline \multirow{2}{*}{$\begin{array}{l}\text { Rainfall } \\
\text { Districts }\end{array}$} & \multicolumn{3}{|l|}{ RCP 4.5} & \multicolumn{3}{|l|}{ RCP 8.5} \\
\hline & Near term & Mid term & End term & Near term & Mid term & End term \\
\hline Raya Alamata & 2.8 & 1.3 & 3.0 & 5.2 & 4.0 & 8.2 \\
\hline Ofla & 1.6 & 2.7 & 4.4 & 6.6 & 5.4 & 9.6 \\
\hline Enda-Mekoni & 2.7 & 3.3 & 5.3 & 6.3 & 5.1 & 7.1 \\
\hline Raya Azebo & 7.1 & 10.3 & 16.6 & 8.5 & 16.1 & 28.7 \\
\hline
\end{tabular}




\section{Projection of meteorological droughts}

The temporal variation of projected RDI in RayaAlamata, Raya-Azebo, Ofla, and Enda-Mekoni districts are given in (Fig. 2a-h). Even though the future projected rainfall increases, the RDI results depend on the temperature, which indicate drought in the region. In all districts RDI can be observed that in the current period in the years 1983, 1984, 2013, and 2014 had the maximum severity indicated extreme drought with the magnitude range between -2.10 to -2.86 . Indeed, these years were among the worst drought years in the history of Ethiopia (Bayissa et al. 2015; Edossa et al. 2010; Gebrehiwot et al. 2011; Yisehak and Zenebe 2020). Numerous investigations show that severe drought have been occurred in these years and caused substantial damage in terms of life and economic losses (Bayissa et al. 2015; Edossa et al. 2010; Gebrehiwot et al. 2011). While, due to climate change impact in the future years 2043, 2044, 2073, and 2074 extreme drought will be occurred with magnitude range between -2.07 to -2.69 under both emission scenarios, except Raya-Azebo will be observed moderate drought. The drought events reached its maximum value in the region in the mid-term and end-term periods. The result of this research have also similarities with research findings of Gidey et al. (2018) which were carried out in Raya valley. At the same time studies by Gebrehiwot et al. (2011) also confirm that the drought will increase at an alarming rate due to climate change for the future in region.

\section{Drought characteristics}

In preparation for drought mitigation, it is important to understand the drought characteristics through drought analysis. It consists of reliable information as the primary factor in the decision-making process (Wilhite and Svoboda 2000). As shown in the Table 6, RDI summary results of duration, severity, intensity, and relative frequency for each district with the 12-month timesscales. Recapitulation has shown the apparent difference in duration, severity, intensity, and relative frequency of each districts, it describes the characteristics of drought in one district had difference with other district. The highest duration of RDI of 6-years was predicted under RCP 4.5 emission scenario in Ofla, Enda Mekoni, and Raya Alamata districts. In Ofla district the highest length of drought (duration was recorded) in the current year and in the mid-term, whereas in Enda-Mekoni only in the mid-term. In Raya Alamata district, observation was for the current, near-term, and mid-term. RCP 8.5 emission scenario ware predicted the highest of drought duration of 7-years and it was in Ofla and Raya Alamata districts in the mid-term. Experts have long predicted that the frequency and intensity of droughts would increase as a result of climate change, especially in semi-arid areas (Zhao and Dai 2015).

\section{Spatial variation maps of drought severity}

The variation of drought characteristics spatial coverage has been carried out using RDI by interpolation of the RDI values of the driest year at various districts

Table 5 Validation statistics of climate modeling performance

\begin{tabular}{|c|c|c|c|c|c|c|c|}
\hline \multirow[t]{2}{*}{ Distracts } & \multirow[t]{2}{*}{ Evaluation } & \multicolumn{3}{|l|}{ RCP 4.5} & \multicolumn{3}{|l|}{ RCP 8.5} \\
\hline & & Rainfall & Tmax & Tmin & Rainfall & Tmax & Tmin \\
\hline \multirow[t]{4}{*}{ Raya Alamata } & RMSE & 15.30 & 5.80 & 3.02 & 26.30 & 5.95 & 3.23 \\
\hline & MAE & 0.21 & 0.21 & 0.15 & 0.27 & 0.17 & 0.16 \\
\hline & $\mathrm{RE}$ & 1.10 & 0.20 & -0.10 & 1.00 & -0.20 & -0.20 \\
\hline & $R^{2}$ & 0.81 & 0.98 & 0.93 & 0.75 & 0.93 & 0.91 \\
\hline \multirow[t]{4}{*}{ Ofla } & RMSE & 10.10 & 4.50 & 3.50 & 13.20 & 5.50 & 4.24 \\
\hline & MAE & 5.74 & 0.32 & 0.22 & 0.57 & 0.19 & 0.14 \\
\hline & $\mathrm{RE}$ & 1.50 & 0.12 & -0.20 & 1.40 & 0.10 & -0.20 \\
\hline & $R^{2}$ & 0.87 & 0.91 & 0.95 & 0.89 & 0.98 & 0.97 \\
\hline \multirow[t]{4}{*}{ Enda-Mekoni } & RMSE & 17.20 & 3.80 & 2.02 & 22.30 & 4.15 & 2.13 \\
\hline & MAE & 1.61 & 0.51 & 0.45 & 1.77 & 0.17 & 0.36 \\
\hline & $\mathrm{RE}$ & 1.15 & 0.30 & -0.10 & 1.30 & 0.20 & -0.20 \\
\hline & $R^{2}$ & 0.71 & 0.98 & 0.94 & 0.85 & 0.96 & 0.91 \\
\hline \multirow[t]{4}{*}{ Raya-Azebo } & RMSE & 20.10 & 1.50 & 2.50 & 23.20 & 2.50 & 3.24 \\
\hline & MAE & 1.74 & 0.37 & 0.32 & 1.57 & 0.49 & 0.44 \\
\hline & $\mathrm{RE}$ & 1.90 & 0.02 & -0.20 & 0.60 & 1.10 & -0.20 \\
\hline & $R^{2}$ & 0.82 & 0.99 & 0.95 & 0.85 & 0.99 & 0.98 \\
\hline
\end{tabular}



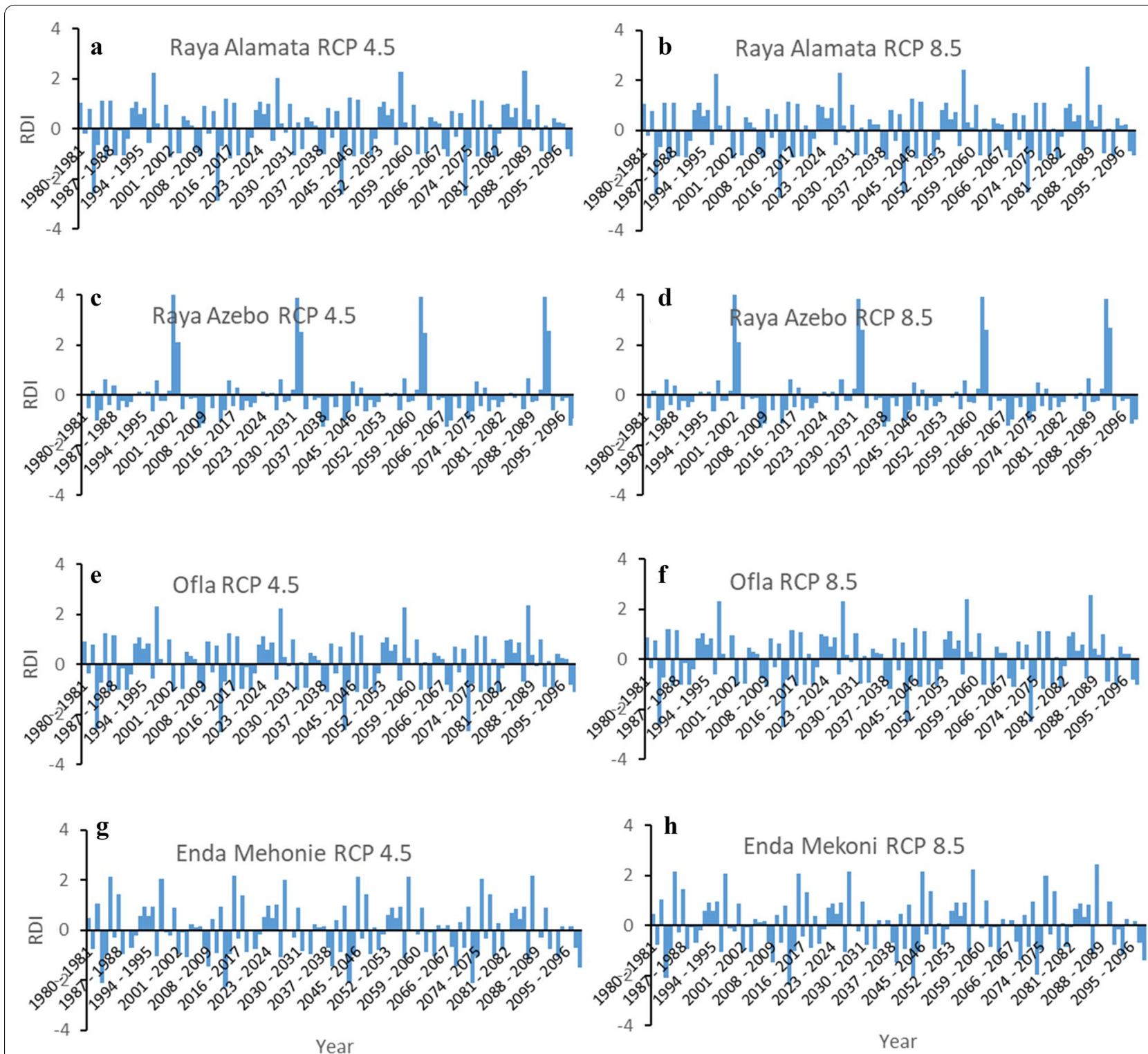

Fig. 2 RDI value calculation from observed (1980-2009) and projected rainfall and temperature data at Raya Alamata (a, b), Raya Azebo (c, d), Ofla $(\mathbf{e}, \mathbf{f})$, and Enda Mekoni (g, h) district during in 2021-2099 under RCP 4.5 and RCP 8.5 emission scenarios

for the 12 months' meteorological drought. The analysis has been carried out in ArcGIS using the inverse distance weighted (IDW) method. The duration and deficit volume severity of a spatial drought event, at a particular time, is relevant information for drought management.

In current time-series, the RDI drought shows $71 \%$ covers extreme drought in southern districts in all part of Ofla and Raya Alamata and nearly in Enda Mekoni and Raya Azebo districts. The RCP 4.5 emission scenarios projection shows that the spatial coverage of RDI drought expected to be $81 \%, 70 \%$, and $74 \%$ in the near-term, mid-term, and end-term period, respectively and this extreme drought can happen some part of southern Tigray, as in ofla, Raya Azebo, and Raya Alamata and in almost half parts of Enda Mekoni district. While, RCP 8.5 emission scenarios projection shows in all districts the spatial coverage of RDI expected to be $65 \%$ and $58 \%$ in the mid-term and end-term periods, respectively, extreme drought can happen in ofla, and Raya Alamata and nearly Raya Azebo districts. While, $33 \%$ severe drought will be expected Enda Mekoni given in the Fig. 3.The spatial analysis of drought shows that most of the drought 
Table 6 Recapitulation of Projected drought events for RDI-12

\begin{tabular}{|c|c|c|c|c|c|c|c|c|c|c|}
\hline \multirow[t]{2}{*}{ No. } & \multirow[t]{2}{*}{ Districts } & \multirow[t]{2}{*}{ Period } & \multicolumn{4}{|c|}{ RCP 4.5} & \multicolumn{4}{|c|}{ RCP 8.5} \\
\hline & & & D & $S$ & I & $\mathrm{RF} \%$ & $\mathrm{D}$ & $S$ & I & RF\% \\
\hline \multirow[t]{4}{*}{1} & \multirow[t]{4}{*}{ Ofla } & Current & 6 & 7.9 & 1.3 & 20 & 6 & 7.9 & 1.3 & 20 \\
\hline & & Near-term & 5 & 7.0 & 1.4 & 20 & 5 & 7.0 & 1.4 & 20 \\
\hline & & Mid-term & 6 & 7.9 & 1.3 & 20 & 7 & 8.8 & 1.3 & 20 \\
\hline & & End-term & 5 & 7.1 & 1.4 & 20 & 5 & 6.8 & 1.4 & 20 \\
\hline \multirow[t]{4}{*}{2} & \multirow[t]{4}{*}{ Raya Azebo } & Current & 3 & 3.5 & 1.2 & 10 & 3 & 3.5 & 1.2 & 10 \\
\hline & & Near-term & 3 & 3.4 & 1.1 & 10 & 3 & 3.5 & 1.2 & 10 \\
\hline & & Mid-term & 3 & 3.3 & 1.1 & 10 & 2 & 2.2 & 1.1 & 10 \\
\hline & & End-term & 1 & 1.2 & 1.2 & 10 & 2 & 2.2 & 1.1 & 10 \\
\hline \multirow[t]{4}{*}{3} & \multirow[t]{4}{*}{ Enda-Mekoni } & Current & 5 & 6.7 & 1.3 & 20 & 5 & 6.7 & 1.3 & 20 \\
\hline & & Near-term & 3 & 4.8 & 1.6 & 10 & 4 & 5.9 & 1.5 & 10 \\
\hline & & Mid-term & 4 & 5.7 & 1.4 & 10 & 5 & 6.6 & 1.3 & 20 \\
\hline & & End-term & 6 & 7.9 & 1.3 & 20 & 5 & 6.6 & 1.3 & 20 \\
\hline \multirow[t]{4}{*}{4} & \multirow[t]{4}{*}{ Raya Alamata } & Current & 6 & 8.1 & 1.4 & 20 & 6 & 8.1 & 1.4 & 20 \\
\hline & & Near-term & 6 & 8.2 & 1.4 & 20 & 5 & 7.0 & 1.4 & 17 \\
\hline & & Mid-term & 6 & 7.9 & 1.3 & 20 & 7 & 6.3 & 0.9 & 23 \\
\hline & & End-term & 5 & 7.1 & 1.4 & 17 & 6 & 7.9 & 1.3 & 20 \\
\hline
\end{tabular}

$D$ Length of drought (Duration) in the year, $S$ Severity, I Intensity, $R F$ relative frequency

frequency and extreme events are recorded in the region. The majority of the region experienced severe and extreme drought event. The Spatial drought risk events indicate a potential hazard to the rain-feed agriculture (Gebrehiwot et al. 2011; Yirga 2020).

\section{Conclusions}

Projected mean annual temperature and rainfall show that an increasing trend in the future climate. The projected precipitation reveals an annual increase for all the three-time scales (i.e. near-term, mid-term, and

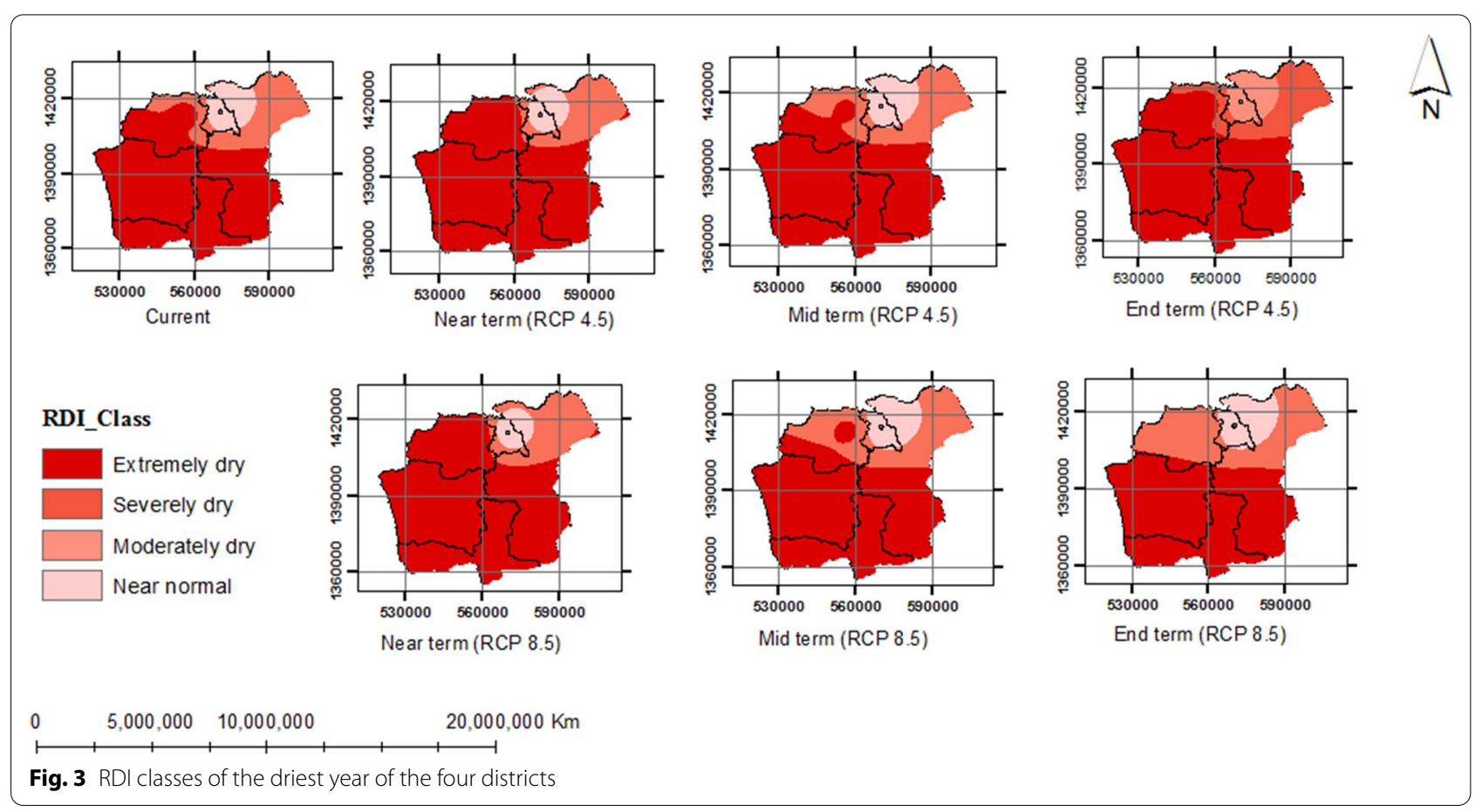


end-term) in both RCP 4.5 and RCP 8.5 emission scenario over the southern part of Tigray.

The drought conditions in Ofla and Raya Azebo districts will continue without changing the current drought frequency. In the other two districts show an increasing and a decreasing in drought frequency under changing climate, prominent to higher risk in terms of strengthened destruction of drought. This in turn delivers indication for proper policy enforcement to safeguard and control drought and flooding associated risks in the study area. Spatial extent of meteorological drought, they are almost the same to the study area, but unlikely for meteorological drought characteristics of duration, intensity, and relative frequency, because of the result had different in magnitude.

The current and future spatial coverage of drought in the study area affected by extreme drought and the remain percent affected by severely and moderate drought. The entire study area of those four districts can be considered as drought prone areas. Thus, different land and water management activities should be implemented in place to minimize the drought impacts in the region.

\section{Acknowledgements}

The research was supported by Mekelle University small scale research fund of registration number of the project under Institute of Climate and Society (ICS). We would like also to acknowledge National Meteorological Agency (NMA) of Ethiopia.

\section{Authors' contributions}

$B Y$ developed the design of the model, analyze and evaluated the results, and $B Y, H S$ and $H A$ drafted the manuscript. AG, HH, KA, and TB read and approved the final manuscript. All authors read and approved the final manuscript.

\section{Funding}

This work was financially supported by Mekelle University under Institute of Climate and Society (ICS) small scale research grant registration number CPO/ ICS/Small/Recurrent/001/2010.

\section{Availability of data and materials}

Not applicable.

\section{Declarations}

Ethics approval and consent to participate

Not applicable.

\section{Consent for publication}

Not applicable.

\section{Competing interests}

The authors declared that there is no conflict of interest.

\section{Author details}

${ }^{1}$ Institute of Climate and Society, Mekelle University, Mekelle, Ethiopia.

${ }^{2}$ African Center of Excellence in Climate Change, Biodiversity \& Sustainable Agriculture (CEA-CCBAD), University Felix Houphouët-Boigny, Abidjan, Côte $d^{\prime}$ Ivoire. ${ }^{3}$ Faculty of Geo-information Science and Earth Observation Science and Earth Observation (ITC), University of Twente, Mekelle, The Netherlands.
Received: 1 October 2020 Accepted: 8 March 2021

Published online: 17 March 2021

\section{References}

Araya A, Hoogenboom G, Luedeling E, Hadgu KM, Kisekka I, Martorano LG (2015) Assessment of maize growth and yield using crop models under present and future climate in southwestern Ethiopia. Agric For Meteoro 214-215:252-265. https://doi.org/10.1016/j.agrformet.2015.08.259

Ashenafi AA (2014) Modeling Hydrological Responses to Changes in Land Cover and Climate in Geba River Basin, Northern Ethiopia. PhD Thesis, Freie University of Berlin, Germany, 187

Ault TR, Mankin JS, Cook BI, Smerdon JE (2016) Relative impacts of mitigation, temperature, and precipitation on 21st-century megadrought risk in the American Southwest. Sci Adv 2(10):e1600873

Ayenew T, GebreEgziabher M, Kebede S, Mamo S (2013) Integrated assessment of hydrogeology and water quality for groundwater-based irrigation development in the Raya Valley, northern Ethiopia. Water international 38(4):480-492

Bayissa YA, Moges SA, Xuan Y, Van Andel SJ, Maskey S, Solomatine DP, Griensven A, Van, Tadesse T (2015) Spatio-temporal assessment of meteorological drought under the influence of varying record length: The case of Upper Blue Nile Basin, Ethiopia. Hydrol Sci J 60(11):1927-1942

Bordoy R, Burlando P (2013) Bias correction of regional climate model simulations in a region of complex orography. Journal of Applied Meteorology Climatology 52(1):82-101

Doorenbos J (1975) Guidelines for predicting crop water requirements. Food and Agriculture Organization. Rome, Irrig. Drainage Pap., 24

Edossa DC, Babel MS, Gupta A, Das (2010) Drought analysis in the Awash river basin, Ethiopia. Water Resour Manage 24(7):1441-1460. https://doi.org/ 10.1007/s11269-009-9508-0

Elshamy M, Seierstad IA, Sorteberg A (2009) Impacts of climate change on Blue Nile flows using bias-corrected GCM scenarios. https://doi.org/10. 5194/hess-13-551-2009

Gebrehiwot T, van der Veen A, Maathuis B (2011) Spatial and temporal assessment of drought in the Northern highlands of Ethiopia. Int J Appl Earth Obs Geoinf 13(3):309-321. https://doi.org/10.1016/j.jag.2010.12.002

Gidey E, Dikinya O, Sebego R, Segosebe E, Zenebe A (2018) Predictions of future meteorological drought hazard ( 2070) under the representative concentration path (RCP) 4.5 climate change scenarios in Raya, Northern Ethiopia. Model Earth Syst Environ 4(2):475-488. https://doi.org/10.1007/ s40808-018-0453-x

Giorgi F, Marinucci MR, Visconti G (1992) A 2XCO2 climate change scenario over Europe generated using a limited area model nested in a general circulation model 2. Climate change scenario. J Geophys Res 97(D9):10011-10028

Graham LP, Andréasson J, Carlsson B (2007) Assessing climate change impacts on hydrology from an ensemble of regional climate models, model scales and linking methods-a case study on the Lule River basin. Clim Change 81(1):293-307

Hargreaves GH, Samani ZA (1982) Estimating potential evapotranspiration. J Irrig Drain Div 108(3):225-230

Hargreaves GH, Samani ZA (1985) Reference crop evapotranspiration from temperature. Appl Eng Agric 1(2):96-99. https://doi.org/10.13031/2013. 26773

Hay LE, Wilby RL, Leavesley GH (2000) A comparison of delta change and downscaled GCM scenarios for three mountainous basins in the United States 1. JAWRA Journal of the American Water Resources Association 36(2):387-397

Kanellou E, Domenikiotis C, Blanta A, Hondronikou E, Dalezios NR (2008) Index-based drought assessment in semi-arid areas of Greece based on conventional data. European Water 23(24):87-98

Kim K-H, Kabir E, Ara Jahan S (2014) A review of the consequences of global climate change on human health. Journal of Environmental Science Health Part C 32(3):299-318

Leander R, Buishand TA (2007) Resampling of regional climate model output for the simulation of extreme river flows. J Hydrol 332(3-4):487-496

Loukas A, Vasiliades L (2004) Probabilistic analysis of drought spatiotemporal characteristics inThessaly region, Greece. Natural Hazards Earth System Science 4(5/6):719-731 
Masih I, Maskey S, Mussá FEF, Trambauer P (2014) A review of droughts on the African continent: a geospatial and long-term perspective. Hydrol Earth Syst Sci 18(9):3635-3649

Nicholson SE (2000) The nature of rainfall variability over Africa on time scales of decades to millenia. Global Planet Change 26(1-3):137-158

Ouédraogo WAA, Gathenya JM, Raude JM (2019) Projecting Wet Season Rainfall Extremes Using Regional Climate Models Ensemble and the Advanced Delta Change Model: Impact on the Streamflow Peaks in Mkurumudzi Catchment. Kenya Hydrology 6(3):76

Pal JS, Small EE, Eltahir EAB (2000) Simulation of regional-scale water and energy budgets: Representation of subgrid cloud and precipitation processes within RegCM. Journal of Geophysical Research: Atmospheres 105(D24):29579-29594

Rivas-Martínez S, Costa M, Sánchez-Mata D (1999) North American boreal and western temperate forest vegetation. Departamento de Biología Vegetal (Botánica), Facultad de Biología, Campus Vegazana, Universidad de León

Rosenzweig C, Jones JW, Hatfield JL, Ruane AC, Boote KJ, Thorburn P, Antle JM, Nelson GC, Porter C, Janssen S (2013) The agricultural model intercomparison and improvement project (AgMIP): protocols and pilot studies. Agric For Meteorol 170:166-182. https://doi.org/10.1016/j.agrformet. 2012.09.011

Saravi MM, Safdari AA, Malekian A (2009) Intensity-duration-frequency and spatial analysis of droughts using the standardized precipitation index. Hydrol Earth Syst Sci Dis 6(2):1347-1383. https://doi.org/10.5194/ hessd-6-1347-2009

Sarr MA, Seidou O, Tramblay Y, Adlouni E (2015) Comparison of downscaling methods for mean and extreme precipitation in Senegal. J Hydrol 4:369-385

Shepard D (1968) A two-dimensional interpolation function for irregularlyspaced data. In Proceedings of the 1968 23rd ACM national conference (pp. 517-524). ACM

Sillmann J, Roeckner E (2008) Indices for extreme events in projections of anthropogenic climate change. Climatic Change 86(1):83-104

Sousa PM, Trigo RM, Aizpurua P, Nieto R, Gimeno L, Garcia-Herrera R (2011) Trends and extremes of drought indices throughout the 20th century in the Mediterranean. Nat Hazards Earth Syst Sci 11(1):33-51

Stocker T (2014) Climate change 2013: the physical science basis: Working Group I contribution to the Fifth assessment report of the Intergovernmental Panel on Climate Change. Cambridge University Press, Cambridge

Teutschbein C, Seibert J (2013) Is bias correction of regional climate model (RCM) simulations possible for non-stationary conditions? Hydrol Earth Syst Sci 17(12):5061-5077

Thomas T, Jaiswal RK, Galkate RV, Nayak TR (2016) Reconnaissance drought index based evaluation of meteorological drought characteristics in Bundelkhand. Procedia Technol 24:23-30
Tigkas D (2008) Drought characterisation and monitoring in regions of Greece. Eur Water 23(24):29-39

Tigkas D, Vanghelis H, Pangalou D (2013) DrinC, Drought Indices CalculatorGetting Started Guide, version 1.5., National Technical University of Athens, Centre for the Assessment of Natural Hazards \& Proactive Planning \& Lab. of Reclamation Works and Water Resources Management

Tsakiris G, Vangelis H (2005) Establishing a drought index incorporating evapotranspiration. Eur Water 9(10):3-11

Tsakiris G, Tigkas D, Vangelis H, Pangalou D (2007) Regional drought identification and assessment. Case study in Crete. In Methods and tools for drought analysis and management (pp. 169-191). New York: Springer

Tsakiris G, Nalbantis I, Pangalou D, Tigkas D, Vangelis H (2008) Drought meteorological monitoring network design for the reconnaissance drought index (RDI). In: Proceedings of the 1st International Conference "Drought management: scientific and technological innovations". Zaragoza, Spain: option Méditerranéennes, series A (p. 2008)

Vangelis H, Tigkas D, Tsakiris G (2013) The effect of PET method on Reconnaissance Drought Index (RDI) calculation. J Arid Environ 88:130-140

Wagaw M, Coleman T, Tsegaye T, Tadesse W (2005) GIS implementation to support poverty reduction policy and drought management in Ethiopia. In: Fourth Meeting of the Committee on Development Information (CODI IV), Addis Ababa, Ethiopia

Wilhite DA, Svoboda MD (2000) Drought early warning systems in the context of drought preparedness and mitigation. Early Warning Systems for Drought Preparedness and Drought Management, 1-21

Yirga SA (2020) Spatio-temporal analysis of drought variability in central Ethiopia. J Water Clim Change

Yisehak B, Zenebe A (2020) Modeling multivariate standardized drought index based on the drought information from precipitation and runoff: a case study of Hare watershed of Southern Ethiopian Rift Valley Basin. Model Earth Syst Environ. 6:0123456789. https://doi.org/10.1007/ s40808-020-00923-6

Zhao T, Dai A (2015) The magnitude and causes of global drought changes in the twenty-first century under a low-moderate emissions scenario. J Clim 28(11):4490-4512

\section{Publisher's note}

Springer Nature remains neutral with regard to jurisdictional claims in published maps and institutional affiliations.

\section{Submit your manuscript to a SpringerOpen ${ }^{\circ}$ journal and benefit from:}

- Convenient online submission

- Rigorous peer review

- Open access: articles freely available online

- High visibility within the field

- Retaining the copyright to your article

Submit your next manuscript at springeropen.com 